\title{
Single-port thoracoscopic talc pleurodesis for malignant pleural effusion
}

\section{Malign plevral efüzyonlarda tek port torakoskopik plöredez}

\author{
Muharrem ÖZKAYA
}

University of Health Sciences, Antalya Training and Research Hospital, Antalya/TURKEY

\begin{abstract}
Aim: The aim of this study was to evaluate the efficacy of single-incision thoracoscopic surgery (SITS) talc pleurodesis for malignant pleural effusion.

Material and Methods: We examined the medical records of all consecutive patients with malignant pleural effusion who underwent single port thoracoscopic pleurodesis from 2014 to 2018 at the Health Sciences University Antalya Practice and Research Center. There were 30 males (54.5\%) and 25 females (45.4\%), ranging in age from 35 to 88 years (mean age: 64.0 years). Pleurodesis was achieved by insufflation of $4 \mathrm{~g}$ of sterile asbestos-free talc; the chest tube was left in place a minimum of 3 days and was removed when fluid drainage was less than $100 \mathrm{ml} / 24 \mathrm{~h}$. Patients were discharged the day after chest tube removal and a return visit was scheduled on the 30th post-operative day, for clinical evaluation and for a new chest radiograph. Pleurodesis was regarded as successful if the amount of the fluid on chest radiograph on the 30 th post-operative day showed a pleural effusion occupying less than one-fourth of the pleural space.
\end{abstract}

Results: The main causes of malignant pleural effusion were non-small cell lung carcinoma and breast cancer. Major symptoms were dyspnea, chest pain and radiographic findings of pleural fluid. The effusion was on the right side in 40 patients (72.7\%) and on the left side in 15 (27.2\%). There was no intraoperative mortality. The postoperative complication rate was $10.9 \%$ ( 6 patients), and included fever in 1.8\% (one patient) and chest pain in $9.0 \%$ (5 patients) of the patients. Duration of postoperative pleural drainage ranged between 3 and 13 days (mean: 3.36 days). The postoperative hospital stay ranged from 3 to 15 days (mean: 5.6 days). A successful pleurodesis was achieved in 34 of 55 patients (61.8\%).

Conclusion: SITS talc pleurodesis is an effective and safe treatment for the management of malignant pleural effusion.

Key Words: malignant; pleural effusion; pleurodesis 


\section{Öz}

Amaç: Malign plevral efüzyonda tek port üzerinden yapılan torakoskopik cerrahi (SITS) ile plörodezin etkinliğini değerlendirmek.

Gereç ve Yöntemler: 2014 ila 2018 yılları arasında, Sağlık bilimleri Üniversitesi Antalya Sağlık Uygulama ve Araştırma Merkezinde malign plevral efüzyon nedeniyle tek port torakoskopik plöredez uygulanan hastaların medikal kayıtları tarandı. Hastaların 30'u $(\% 54,5)$ erkek ve 25'i $(\% 45,4)$ kadın olup, yaşları 35 ila 88 yaş (ort. 64 yaş) arasında değişmekteydi. Hastalara tek port üzerinden $4 \mathrm{gr}$ asbestsiz steril talk insuflasyonu ile plöredez yapıldı. En az üç gün süre ile göğüs dreni takılı kalan hastalarda günlük drenaj miktarı $100 \mathrm{ml}$ altına düşmesi ile drenleri çekildi. Drenleri çekilerek taburcu edilen hastalara ameliyat sonrası otuzuncu güne klinik değerlendirme ve son akciğer grafilerini görmek amacıyla poliklinik randevusu verildi. Ameliyat sonrası 30. günde kontrole gelen hastaların çekilen göğüs radyografileri değerlendirilerek, kontrol grafisinde o taraf plevral boşluğun dörtte birini doldurmayan mayisi olan hastalarda plöredez başarılı olarak kabul edildi.

Bulgular: Hastalarda en sık malign plevral efüzyonu nedeni olarak küçük hücreli dışı akciğer kanserleri ve meme kanseri tespit edildi. En sık gözlenen belirti ve bulgular dispne, göğüs ağrısı ve radyolojik plevral sıvı bulgularıydı. Efüzyon 40 $(\% 72,7)$ hastada sağ ve $15(\% 27,2)$ hastada sol tarafta gözlendi. Hiçbir hastada intraoperatif mortalite gözlenmedi. Postoperatif komplikasyon oranı \%10,9 (6 hasta) olup bunlar \%1,8 (bir hasta) ile ateş ve \%9,0 (5 hasta) göğüs ağrısı olarak belirlendi. Postoperatif drenaj süresi 3 ila 13 gün (ort. 3,36 gün) ve hastanede kalış süresi 3 ila 15 gün (ort. 5,6 gün) arasında değişmekteydi. Toplamda 55 hastanın 34'ünde $(\% 61,8)$ plöredez başarısının sağlandığı görüldü.

Sonuç: SITS ile talk plörodezis malign plevral efüzyonların tedavisinde etkili ve güvenli bir yöntemdir.

Anahtar Kelimeler: malign; plevral efüzyon; plörodezis

\section{Introduction}

The discovery of malignant cells in pleural fluid and/or parietal pleura signifies disseminated or advanced disease and a reduced life expectancy in patients with cancer[1]. Annual incidence of malignant pleural effusion in Europe is estimated to between 375000 and 400000 per year [2]. Lung cancer is the most common metastatic tumor to the pleura in men and breast cancer in women so that both malignancies together account for $50-65 \%$ of all malignant effusions [3].

Observation, therapeutic pleural aspiration, intercostal tube drainage and instillation of sclerosant, thoracoscopy and pleurodesis or placement of an indwelling pleural catheter are the management options for malignant pleural effusions. Current guidelines recommend pleurodesis to prevent the recurrence of effusion in patients with symptomatic malignant pleural effusions [4].

Among sclerosing agents, talc has been shown to have the highest efficacy.

Instead of classicalVATS which is performed with three ports, singleincision thoracoscopic surgery (SITS) is becoming increasingly popular and is now preferred procedure in many thoracic surgery centers in the management of pleural effusions $[5,6]$.
The aim of this study was to report the results of a consecutive series of pleurodesis for malignant pleural effusion performed by SITS in our department.

\section{Material and Methods}

Medical records of 119 patients who were referred to our Thoracic Surgery Department for suspicion of malignant pleural effusions from 2014 to 2018 at the Health Sciences University Antalya Practice and Research Center were reviewed, with 55 cases fitting for inclusion criteria. Patients were included if they initially had a diagnostic thoracentesis before SITS pleurodesis, if patients were symptomatic or if pleural effusions were recurrent or refractory to medical treatment. Effusions of patients with recent myocardial infarction or cardiac failure, clotting disorders, poor performance status (Karnofsky performance index $\leq 30$ ) or life expectancy less than 2 months, were managed by other than SITS. Management options for these patients included therapeutic pleural aspiration, intercostal tube drainage and pleurodesis. In nine terminally ill patient therapeutic pleural aspirations provided transient relief of symptoms. Four-teen patients with central pulmonary lesion were taught to be with trapped lung were managed by insertion of a tunnelled pleural 
catheter. Intercostal chest tube drainage and pleurodesis was the management option for the remaining fourty-one patient. Diagnoses of malign pleural effusions were established either preoperatively by cytological examination of thoracentesis fluid (51 patients) or peroperatively by frozen-section (4 patients). There were 30 males (54.5\%) and 25 females (45.4\%), ranging in age from 35 to 88 years (mean age: 64.0 years). A complete blood count, clotting tests, and routine biochemical tests were performed preoperatively.

A written consent was obtained for the SITS pleural drainage, biopsy and pleurodesis procedure from each patient. The study was conducted in accordance with the principles of the Declaration of Helsinki. This study was approved by our Institutional Ethics Committee (2018-143).

SITS was performed either under general anesthesia with a double-lumen endotracheal tube for ipsilateral lung collapse or under local anesthesia, sedation and spontaneous ventilation depending on the patients' performance status. Patients were positioned and draped as for a standard posterolateral thoracotomy. The safest point for thoracentesis was planned preoperatively according to the chest radiograph, tomography or thoracic ultrasound. In most cases, intersection of the midaxillary line and the fifth or sixth intercostal space was the site of thoracentesis and eventually the site of thoracoport entry. After local anesthesia was obtained with $10 \mathrm{ml}$ lidocaine injected in the planned intercostal space; a thoracentesis was performed from the pleural effusion for biochemical, microbiological, and pathological examination. A $10.5-\mathrm{mm}$ single thoracoport was used to enter the thorax after single skin incision. A 10- $\mathrm{mm}$ thoracoscope with a 6-mm working channel was used for the procedure. First the pleural effusion was aspirated with a suction catheter. After the aspiration was accomplished, the pleura and the lung were inspected. A simple pleural biopsy with a forceps through the thoracoscope was performed in patients with the unknown primary cancer and those with pleural nodules or any case of pleural abnormality. Additional injection of lidocaine was applied at the site of pleural biopsy required for a diagnostic purpose in patients with sedation. Fro patients under general anesthesia, the degree of lung expansion was ascertained with sustained positive pressure ventilation. If re-expansion of the lung was not proper, partial lung decortication was performed. Care was taken in order to aspirate all the pleural fluid in the pleural cavity. If pleural fluid aspiration was satisfactory, pleurodesis was produced by instillation of $4 \mathrm{~g}$ of sterile asbestos-free talc (Steritalc, Novatech, France) which was insufflated with a disposable atomizer under direct vision. At the end of the procedure a $32-\mathrm{F}$ single thorax drain was placed through the thoracoport incision. The chest tube was left in place a minimum of 3 days and was removed when fluid drainage was less than $100 \mathrm{ml} / 24 \mathrm{~h}$. Patients were discharged the day after chest tube removal and a return visit was scheduled on the 30th post-operative day, for clinical evaluation and a new chest radiograph. Pleurodesis was regarded as successful if the amount of the fluid on chest radiograph on the 30th postoperative day showed a pleural effusion occupying less than one-fourth of the pleural space.

\section{Results}

Fifty-five consecutive patients who underwent SITS (26 patients under general anesthesia with a double-lumen endotracheal tube and 29 patients under local anesthesia and sedation) talc pleurodesis for symptomatic or recurrent malignant pleural effusions were enrolled in this study. There were 30 males (54.5\%) and 25 females (45.4\%), ranging in age from 35 to 88 years (mean age: 64.0 years). Dyspnea was the main symptom in patients with malignant pleural effusions, which was observed in 46 patients (83.6\%). Of the 55 patients, $34(61.8 \%)$ patients showed successful pleurodesis, while 21 (38.1\%) patients showed failed pleurodesis.

There was no intraoperative mortality. The postoperative complication rate was $10.9 \%$ (6 patients), and included fever in $1.8 \%$ (one patient) and chest pain in $9.0 \%$ (5 patients) of the patients. Duration of postoperative pleural drainage ranged between 3 and 13 days (mean: 3.36 days). The postoperative hospital stay ranged from 3 to 15 days (mean: 5.6 days).

Table 1 shows the definitive diagnoses of the patients. 24 (43.6\%) patients had lung cancer (22 patients with Non-small Cell lung cancer vs. 2 patients with Small Cell lung cancer). Other cancers included: breast cancer (12 patients), prostate (3 patients), stomach (3 patients), mesothelioma (2 patients), lymphoma (2 patients), colorectal (2 patients), nasopharynx (one patient), cholangiosarcoma (one patient), thyroid (one patient), skin (one patient), pancreas (one patient), ovary (one patient) and undetermined (one patient). 


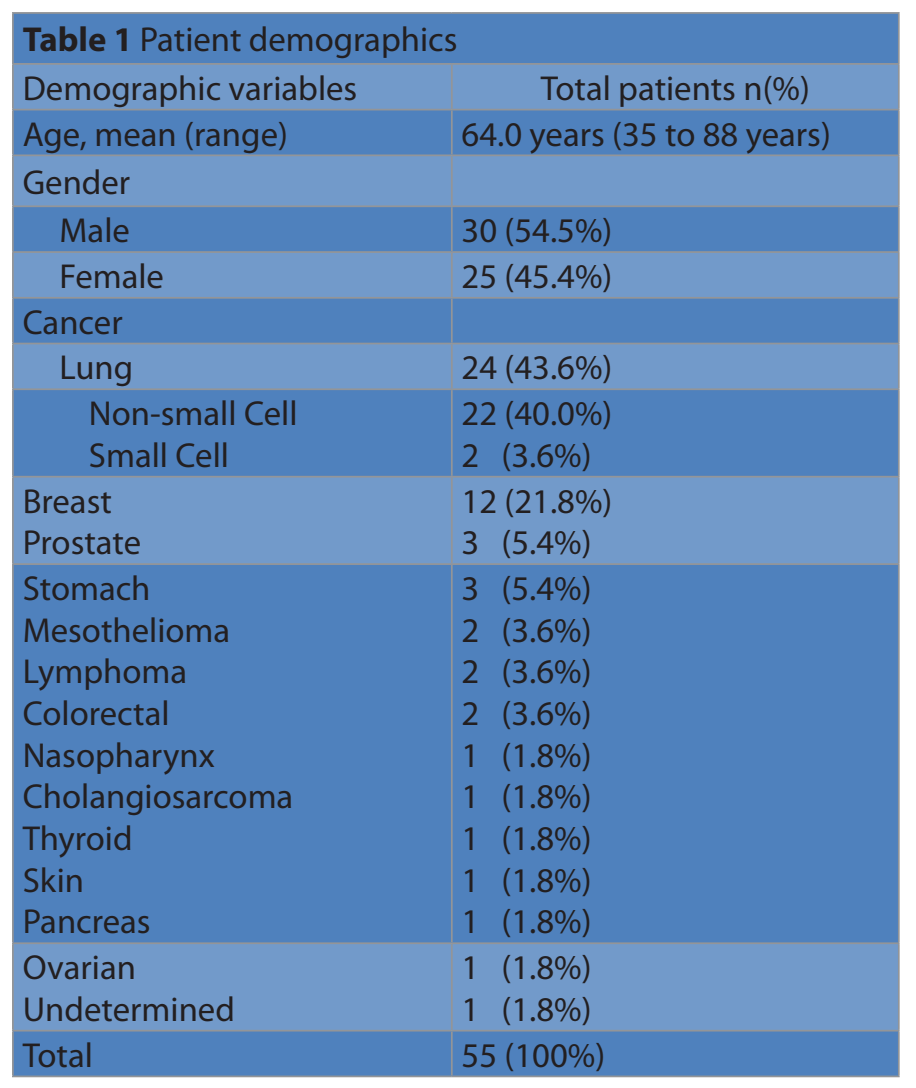

\section{Discussion}

Median survival following diagnosis of malignant pleural effusions ranges from 3 to 15 months and is dependent on the stage and type of the underlying malignancy [1]. The most effective management of malignant pleural effusions includes complete drainage of the effusion and instillation of a sclerosant to promote pleurodesis and prevent recurrence of the effusion. Treatment options are observation, therapeutic pleural aspiration, intercostal tube drainage and instillation of sclerosant, thoracoscopy and pleurodesis or placement of an indwelling pleural catheter. Current guidelines for malignant pleural effusions recommend

VATS talc poudrage for pleurodesis in patients with good performance status [4].

Sixty-four patients managed by treatment options other than SITS were not included to our study because most of these patients were seen on emergency department or intensive care units with severe dyspnea and the main aim of these procedures were urgent relief of symptoms.

Recent reports also support VATS talc pleurodesis in the aspects of efficacy and safety $[7,8]$. SITS on the other hand is actually a uniportal VATS. In contrast to conventional three- port VATS, SITS has the advantages of a single incision, which minimizes the transmission of infection to the incision line and infiltration of the tumor to the skin, subcutaneous tissues, and chest wall in cases of malignant disease such as mesothelioma $[6,9]$. Reducing the number of access ports allows to avoid multiple skin incisions thus could also decrease the risk of intercostal nerve damage and postoperative chest pain[10].

SITS is not always performed in a patient under general anesthesia with selective intubation but also in a patient under moderate sedation with local anesthesia and spontaneously breathing, which is also named as medical thoracoscopy. By this way SITS can also be performed in patients with poor lung function or those with a high anesthetic risk associated with an open procedure.

Pleurodesis is generally used as a palliative procedure in malignant pleural effusions to prevent recurrent fluid accumulation. Many sclerosing agents have been used to carry out an adhesion in the pleural cavity, including tetracycline hydrochloride and its derivatives (doxycycline, minocycline), bleomycin, quinacrine, sodium hydroxide, silver nitrate and Corynebacterium parvum. Talc was found to be the best sclerosant according to the American Thoracic Society and European Respiratory Society Task force consensus statement for the management of malignant pleural effusion [11]. Although there is an uncertainty whether the technique for administering talc affects the outcome, a meta-analysis showed that thoracoscopic insufflation of talc was more effective in achieving non-recurrence of the effusion as compared to bedside instillation of talc slurry through a chest tube [12]. Furthermore in a recent meta-analysis in which twenty trials involving 1,525 patients with malignant pleural effusion were included, the success rate of talc pleurodesis was found to be significantly higher than that of control therapies with similar adverse events. In addition, thoracoscopic talc poudrage was more effective than bedside talc slurry [13]. In our study, we used single port thoracoscopic talc insufflation of in our patients with malignant pleural effusion. Either under local or general anesthesia video thoracoscopic visualization of pleural cavity allows complete aspiration of pleural fluid and eventually dissemination of talc to all dry pleural surfaces.

Pleural effusions are more common in old population with several co-morbidities that often preclude the possibility to perform surgery under general anesthesia[14]. Patients with ASA score three or higher were candidates for SITS under 
local anesthesia and sedation, in our study. We performed non-intubated SITS in $52.7 \%(n=29)$ of our study patients whereas intubated SITS ratio was $47.2 \%(n=26)$. Compared with intubated SITS, the major advantage of non-intubated SITS is its cost-effectiveness for patients with poor tolerance for general anesthesia[15].

Despite less invasive methods, which are, limited in their therapeutic effectiveness as fibrous septa and dense viscous liquid, SITS has the ability to merge pouches, aspirate fibrin debris, and, when necessary, easily perform partial decortication to ensure lung expansion. It was also reported that VATS was found to be a safe, effective, and well-tolerated surgical procedure in patients who have failed to resolve with initial treatment with fibrinolytics [16].

Successful pleurodesis rates ranging between $77-100 \%$ has been reported in studies regarding treatment outcomes for patients undergoing VATS talc pleurodesis for malignant pleural effusion [17-25]. In our study $61.8 \%$ of patients showed successful pleurodesis. This lower success rate may be related to the one-month follow up time in our study. We accepted procedure as unsuccessful in case of any effusion more than one fourth of the same hemithorax in one-month follow up.

The most common major complications associated with thoracoscopic talc poudrage are empyema and acute respiratory failure secondary to infection or re-expansion pulmonary edema [26-28].In our study, we had a $10.9 \%$ postoperative complication rate which included fever in one patient (1.8\%) and chest pain in 6 patients (9.0\%). None of our patients experienced empyema or acute respiratory failure.

\section{Study Limitations}

Our present study was retrospective, and therefore subject to bias. It is also limited in that it was conducted in a single center with a small sample size. Data collection was limited by the completeness of the available patient records.

\section{Conclusion}

SITS talc poudrage is a safe and well-tolerated procedure and also has the ability to obtain a diagnosis, drain the effusion and perform a pleurodesis in selected patients with malignant pleural effusion.

\section{Declaration of conflict of interest}

The authors received no financial support for the research and/or authorship of this article. There is no conflict of interest.

\section{References}

1. Chernow B, Sahn SA. Carcinomatous involvement of the pleura. An analysis of 96 patients. Am J Med 1977; 63: 695-702.

2. Ried M, Hofmann H-S. The treatment of pleural carcinosis with malignant pleural effusion. Dtsch Arztebl Int 2013; 110: 313-18.

3. Sears D, Hajdu SI. The cytologic diagnosis of malignant neoplasms in pleural and peritoneal effusions. Acta Cytol 1987; 31: 85-97.

4. Roberts ME, Neville E, Berrisford RG, Antunes G, Ali NJ. Management of a malignant pleural effusion: British Thoracic Society pleural disease guideline 2010. Thorax 2010; 65

5. Berlanga LA, Gigirey O. Uniportal video-assisted thoracic surgery for primary spontaneous pneumothorax using a single-incision laparoscopic surgery port: A feasible and safe procedure. Surg Endosc Other Interv Tech 2011; 25: 2044-47.

6. Alar T, Ozcelik C. Single-incision thoracoscopic surgery of pleural effusions for diagnosis and treatment. Surg Endosc Other Interv Tech 2013; 27: 4333-36.

7. Basso SMM, Mazza F, Marzano B, Santeufemia DA, Chiara GB, Lumachi $F$. Improved quality of life in patients with malignant pleural effusion following videoassisted thoracoscopic talc pleurodesis. Preliminary results. Anticancer Res 2012; 32:5131-34.

8. MineoTC, SellitriF,Tacconi F, AmbrogiV.Quality of Life and Outcomes after Nonintubated versus Intubated Video-Thoracoscopic Pleurodesis for Malignant Pleural Effusion: Comparison by a CaseMatched Study. J Palliat Med 2014; 17: 761-68

9. Riker D, Sell R. Ultrasound-guided percutaneous biopsy to diagnose indwelling pleural catheter metastasis. J Bronchol Interv Pulmonol 2012; 19: 165-67.

10. MiglioreM. Efficacy and safety of single-trocar technique for minimally invasive surgery of the chest in the treatment of noncomplex pleural disease. J Thorac Cardiovasc Surg 2003; 126: 1618-23.

11. Antony VB, Loddenkemper $R$, Astoul $P$ et al. Management of malignant pleural effusions. Am J Respir Crit Care Med 2000; 162: 1987-2001.

12. Shaw $P$, Agarwal R. Pleurodesis for malignant pleural effusions. Cochrane Database Syst Rev 2004 doi:10.1002/14651858. CD002916.pub2.

13. Xia H, Wang XJ, Zhou Q, Shi HZ, Tong ZH. Efficacy and safety of talc pleurodesis for malignant pleural effusion: A meta-analysis. PLoS One 2014; 9. 
14. Ginsberg RJ. Preoperative assessment of the thoracic surgical patient: a surgeon's viewpoint. In: Pearson G, editor. Thorac. Surg., Churchill Livingstone, NY, USA,; 1995, p. 29-36.

15. Shojaee S, Lee HJ. Thoracoscopy: medical versus surgical-in the management of pleural diseases. J Thorac Dis 2015; 7: 339-51

16. Bouros D, Antoniou KM, Chalkiadakis G, Drositis J, Petrakis I, Siafakas N. The role of video-assisted thoracoscopic surgery in the treatment of parapneumonic empyema after the failure of fibrinolytics. Surg Endosc Other Interv Tech 2002; 16: 151-54.

17. Jones GR. Treatment of recurrent malignant pleural effusion by iodized talc pleurodesis. Thorax 1969; 24: 69-73

18. Harley HRS. Malignant pleural effusions and their treatment by intercostal talc pleurodesis. Br J Dis Chest 1979; 73: 173-77

19. Weissberg D, Ben-Zeev I. Talc pleurodesis. Experience with 360 patients. J Thorac Cardiovasc Surg 1993; 106 :689-95.

20. Hartman DL, Gaither JM, Kesler K a, Mylet DM, Brown JW, Mathur PN. Comparison of insufflated talc under thoracoscopic guidance with standard tetracycline and bleomycin pleurodesis for control of malignant pleural effusions. J Thorac Cardiovasc Surg 1993; 105: 743-47

21. Yim APC, Chan ATC, Lee TW, Wan IYP, Ho JKS. Thoracoscopic talc insufflation versus talc slurry for symptomatic malignant pleural effusion. Ann Thorac Surg 1996; 62: 1655-58
22. Aelony $\mathrm{Y}$, King RR, Boutin C. Thoracoscopic talc poudrage in malignant pleural effusions. Chest 1998; 113: 1007-12

23. Debeljak A, Kecelj P, Triller $\mathrm{N}$ et al. Talc pleurodesis: Comparison of talc slurry instillation with thoracoscopic talc insufflation for malignant pleural effusions. J BUON 2006; 11: 463-67.

24. Foroulis $\mathrm{CN}$, Kotoulas $\mathrm{C}$, Konstantinou $\mathrm{M}$ et al. The management of malignant pleural effusions: talc pleurodesis versus bleomycin pleurodesis. J BUON 2001; 6: 397-400.

25. Kolschmann S, Ballin A, Gillissen A. Clinical efficacy and safety of thoracoscopic talc pleurodesis in malignant pleural effusions. Chest 2005; 128: 1431-35.

26. Menzies R, Charbonneau M. Thoracoscopy for the diagnosis of pleural disease. Ann Intern Med 1991; 114: 271-76.

27. Arapis K, Caliandro R, Stern JB, Girard P, Debrosse D, Gossot D. Thoracoscopic palliative treatment of malignant pleural effusions: Results in 273 patients. Surg Endosc Other Interv Tech 2006; 20: 919-23

28. De Campos JRM, Vargas FS, De Campos Werebe E, Cardoso P, Teixeira LR, Light RW. Thoracoscopy talc poudrage: A 15-year experience. Chest 2001; 119: 801-6. 